\title{
Study of Development Potential Chrysanthemum in Buleleng Regency
}

\author{
I Gusti Made Arjana, Yohanes Parlindungan Situmeang and I Nengah Suaria \\ Faculty of Agriculture, Warmadewa University, Denpasar, Bali, Indonesia \\ E-mail: igm.arjana@gmail.com; ypsitumeang63@gmail.com
}

\begin{abstract}
The purpose of this study was to determine the potential of agro-climate, technology of cultivation, harvest and postharvest chrysanthemums. This study uses survey method, through the collection of primary data and secondary data. This research is located in the village of Pancasari, District Sukasada, Buleleng Bali Province. Descriptive survey conducted on 40 respondents chrysanthemum growers using the component identification of determinants of commodity production chrysanthemum include: site selection, infrastructure, crop production processes and post-harvest handling. The survey results showed that $100 \%$ of the farmers have chosen a suitable location with agro-climatic conditions required by the chrysanthemum plant, and 86.09\% of the farmers have been using the means needed to support the process of crop production. In the process of production of $78 \%$ in accordance with the operational procedures. At the stage of harvest and post-harvest handling $80 \%$ have been implemented by farmers and some still use conventional methods of handling. Thus Pancasari village has a potential location for the cultivation of chrysanthemum as a mainstay commodity.
\end{abstract}

Keywords - Chrysanthemum; Development Potential; Buleleng Bali.

\section{INTRODUCTION}

Chrysanthemum (Dendranthema grandiflora,Tzvelev Syn) or known as the Chrysanthemum flower, is a commodity that has economic value that is high enough so that the potential to be developed commercially as a basic component in the agribusiness good as cut flowers, potted plants, and medicinal plants [8]. The cultivation of chrysanthemums which initially concentrated in Java, has now spread to Bali, this means that the development of ornamental plants in Bali in the future is quite good because it is supported by the natural resources. This reflects that in the interest of the growers of ornamental plants and on the other hand increases the demand for ornamental plants also increased. The increase is due Bali as a tourism and socio-cultural conditions of the people of Bali who wear flowers as a complementary means of religious ceremonies in addition to other purposes.

Production of chrysanthemum flower in Bali have not been able to meet the needs of the market due to low productivity and farm areas are still cultivated by farmers only. The increase in production should be increased either through extension or intensification. Planting chrysanthemums in Bali so far only concentrated in Bedugul area that needs to be developed in other areas of potential. Increased production through intensification frequently encountered problems such as the provision of planting materials (cuttings), especially farmers who are outside the island of Java, spacing arrangement, arrangement of soil moisture by mulching, the determination of the optimum dose of organic and inorganic fertilizers, post-harvest and the management of production systems.

Based on the above, it is necessary to research on potential areas of investment and technology chrysanthemum plant cuttings in a comprehensive manner, which will be used by farmers to support the production and quality of chrysanthemum flowers that also will be able to increase the income of farmers.

The purpose of this study is to obtain the chrysanthemum plant with the potential development of appropriate farming technologies to increase productivity and income of farmers as well as the quality of chrysanthemum plants. Cultivation technology is done by applying site-specific farming technology and other components in an integrated aquaculture and maintain soil fertility, environmental sustainability and sustainable production systems.

\section{RESEARCH METHODS}

The study was conducted in the village of Pancasari (Figure 1), district Sukasada, Buleleng regency of Bali province, with a height of 1,247 meters above sea level and an average temperature of $17^{\circ} \mathrm{C}$ to $20^{\circ} \mathrm{C}$. This study begins in January 2014 and ended in August 2014. 
This study is to assess the potential of agro-climate, crop cultivation technologies, post harvest farming chrysanthemum, using survey methods (collecting primary data and secondary data) for testing recommendation cutting plant material application technology. Survey method of data collection is done by direct interviews with farmers chrysanthemum with questionnaires to the respondents as many as 40 people that lists the components identified determinant factor chrysanthemum crops [3]. Components include site selection, infrastructure, production, harvest and post-harvest, and other components of chrysanthemum production constraints and market facing local farmers.

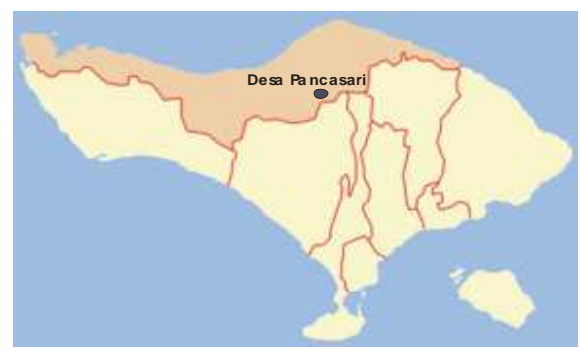

Fig. 1 Map of Study Sites

\section{RESULTS AND DISCUSSION}

Of the 148 villages in Buleleng, Pancasari is a village located on the southern most district of Buleleng. Location of village area Pancasari at position $8^{\circ}$ south latitude and $115^{\circ}$ East Longitude with an area of $12.80 \mathrm{~km}^{2}$. Based on population regestrasi Pancasari number of villagers as much as 4,783 people (2,323 men, 2,460 women) with 1,003 heads of families with livelihood mostly as farmers fields as many as 2,588 inhabitants and agricultural land with an area of 365.73 ha.

TABLE I

Type of Horticultural COMMOdities AND Planting AREA PER Year in The Village PANCASARI

\begin{tabular}{|l|l|c|}
\hline No & Commodities & $\begin{array}{c}\text { Planting Area } \\
\text { (Ha) }\end{array}$ \\
\hline 1 & Cabbage & 74 \\
2 & Carrot & 100 \\
3 & Potato & 36 \\
4 & Large Chili & 9 \\
5 & Tomato & 30 \\
6 & Strawberry & 58 \\
7 & Paprika & 3 \\
8 & Chrysanthemum & 3 \\
9 & Etc & 59 \\
\hline \multicolumn{2}{|c|}{ Total } & 382 \\
\hline
\end{tabular}

Pancasari village is a plateau region located at an altitude of $1,247 \mathrm{~m}$ above sea level surrounded by hills and mountains. Conditions were cold and cool nature of this village has potential as a producer of horticultural products such as fruits, vegetables and flowers, this is because the farmers are creative and innovative with environmental conditions suitable for the growth and development of horticulture. The village is also famous as a producer of strawberries, peppers, lecttuce, potato and tomato plants other potential, which was developed in house protected so that production does not depend on the season. Type horticulture and rural planting area per year Pancasari 2012 are presented in Table 1 [6].
From the table above, chrysanthemum and bell pepper plants occupy the smallest area cultivated in this village per year. Looking at the climate conditions and market opportunities chrysanthemum plants have significant potential to be developed. The results of the survey conducted components include a review of potential agroclimate, cultivation, harvest and post-harvest are presented in Table 2, 3, 4, 5, and 6 .

\section{A. Site Selection}

Each type of plants need different growing conditions so that plants can grow optimally, site selection is less suitable for the cultivation of chrysanthemums will have an impact on the growth and development of plants that are less good. Chrysanthemum cultivation will be successful if $95 \%$ of environmental conditions meet the criteria for the cultivation of chrysanthemums as altitude of about 600-1200 m above sea level, sandy clay soil texture, good drainage, soil $\mathrm{pH}$ ranged from 5.5 to 6.7 , temperature day and night average days $22^{\circ}-28^{\circ} \mathrm{C}$ and $15^{\circ}-20^{\circ} \mathrm{C}$, humidity $70-85 \%$ with a slope of less than $10 \%$. From Table 2 and see the above requirements then Pancasari village has an ideal location requirements $(100 \%)$ for the cultivation of chrysanthemums as a mainstay commodity other than the type of plant that has been cultivated by farmers. This situation illustrates the development of chrysanthemum cultivation can be done in this village because it is supported by sufficient potency, which is supported by the land and climate suitability and supported by a mastery of technology, the availability of extension workers and farmer cooperation between groups [7].

TABLE II

DATA FROM THE SURVEY COMPONENT OF SITE SELECTION

\begin{tabular}{|c|l|c|c|}
\hline \multirow{2}{*}{$\begin{array}{c}\text { N } \\
\text { o }\end{array}$} & \multicolumn{1}{|c|}{ Site Selection } & \multicolumn{2}{c|}{ Component } \\
\cline { 2 - 4 } & & Weight & $\begin{array}{c}\text { Weight } \\
\text { Respondents }\end{array}$ \\
\hline 1 & Environmental conditions & 10 & 10 \\
& Soil pH & 5 & 5 \\
& Soil conditions & 10 & 10 \\
& Elevation & 10 & 10 \\
& Temperature day and night & 10 & 10 \\
& Humidity & 10 & 10 \\
& The slope of the land & 10 & 10 \\
& Around there planting & 5 & 5 \\
& chrysanthemums & & 70 \\
\hline & Total & 70 & \\
\hline
\end{tabular}

\section{B. Infrastructure}

Preparation of protected house aims to get micro-climatic conditions and protect crops from pest attack and environmental stresses directly in order to obtain an optimal environment in which to grow. In the preparation of the protected home that need attention are: the design, shape, material protected home, height, roof and walls of the house protected. From Table 3 can be seen that $94 \%$ of respondents farmers have to follow procedure. This is due to the preparation of the protected houses adapted to local resources and willingness to fund local farmers, most of the material protected using a combination of wood, bamboo and concrete and the roof is used using ultra violet plastic, although some farmers are using the aluminum construction. 
TABLE III

DATA FROM THE SURVEY COMPONENT OF INFRASTRUCTURE

\begin{tabular}{|c|c|c|c|}
\hline \multirow[b]{2}{*}{ No } & \multirow[b]{2}{*}{ Infrastructure } & \multicolumn{2}{|c|}{ Component } \\
\hline & & Weight & $\begin{array}{c}\text { Weight } \\
\text { Respondents }\end{array}$ \\
\hline \multirow[t]{7}{*}{1} & Preparation Home Protected & 80 & 75 \\
\hline & Design house hedge & 10 & 10 \\
\hline & Protected home form & 10 & 10 \\
\hline & Materials used & 15 & 15 \\
\hline & Height of the protected home & 15 & 15 \\
\hline & Roofs protected & 15 & 10 \\
\hline & The wall is protected & 15 & 15 \\
\hline \multirow[t]{4}{*}{2} & Irrigation Facilities & 30 & 30 \\
\hline & Source of water & 10 & 10 \\
\hline & Water channel & 10 & 10 \\
\hline & Area network & 10 & 10 \\
\hline \multirow[t]{6}{*}{3} & Means of lighting installations & 35 & 35 \\
\hline & Tools and materials & 5 & 5 \\
\hline & $\begin{array}{l}\text { Installation of switches and } \\
\text { sockets }\end{array}$ & 5 & 5 \\
\hline & Area network & 10 & 10 \\
\hline & The distance between the lamp & 10 & 10 \\
\hline & Use timers & 5 & 5 \\
\hline \multirow[t]{4}{*}{4} & $\begin{array}{l}\text { The support rod means } \\
\text { Chrysanthemum }\end{array}$ & 25 & 25 \\
\hline & Tools and materials & 5 & 5 \\
\hline & Installation of cantilever & 10 & 10 \\
\hline & The distance between holes & 10 & 10 \\
\hline 5 & $\begin{array}{l}\text { Means of measurement EC, } \mathrm{pH} \text {, } \\
\text { and soil moisture }\end{array}$ & 10 & 0 \\
\hline 6 & $\begin{array}{l}\text { Material and Equipment Use of } \\
\text { plant growth regulators }\end{array}$ & 10 & 0 \\
\hline \multirow[t]{3}{*}{7} & Other Production Facility & 20 & 20 \\
\hline & Grading and packing house & 10 & 10 \\
\hline & Type and post-harvest equipment & 10 & 10 \\
\hline \multirow[t]{6}{*}{8} & Other Production Facility & 20 & 13 \\
\hline & Type and number of devices & 5 & 5 \\
\hline & Storage devices & 5 & 5 \\
\hline & The appliance warehouse & 5 & 3 \\
\hline & Inventaris Notebook & 5 & 0 \\
\hline & Total & 230 & 198 \\
\hline
\end{tabular}

Irrigation (water sources, waterways, extensive tissue), means of lighting installation (materials and equipment, switches and sockets, extensive network, the distance between the lamp and timer), a means of supporting plant stems (equipment and materials, installation cantilever, the distance between hole) and post-harvest facilities (grading and packing house, kind and post-harvest equipment).

Average farmer almost $100 \%$ of the $95 \%$ procedure otherwise qualified to complete the facility in chrysanthemum cultivation, as a means of lighting installation is one of the special tools that must be met in getting the chrysanthemum plant. While other production facilities such as; a tool shed, storage tool type and amount of equipment and inventory notebook is a new procedure to qualify $65 \%$, this is because farmers do not keep records of the owned inventory and warehouse storage place is available but not in accordance with the procedure. While the means of measurement tools $\mathrm{EC}, \mathrm{pH}$, moisture, material and equipment the use of growth regulators in no way owned by farmers, it is associated with the ability of farmers to buy such a device owned by farmers and farmers' lack of knowledge about the function and use of these facilities.

\section{Production Process}

Chrysanthemum plants grown in monoculture on the bed in the hedge that has been prepared, therefore, the production process should be carefully prepared in order to produce excellent quality in accordance with the defined quality standards. Because chrysanthemum production process is different from other types of ornamental plants.

The stages of the production process in the cultivation of chrysanthemum plants (Table 4) include: tillage, sterilization area, a raised bed, setting the supporting plant, the operation of the lamp, measurement (EC, $\mathrm{pH}$ and soil moisture), calcification, selecting quality seeds, planting, weeding, fertilizing, controlling plant pests, weeding, provision of plant growth regulators, pemontesan flower buds, perompesan old leaves and environmental sanitation.

Chrysanthemum cultivation of land by farmers in Pancasari have followed the requirements of the production system in accordance with the procedure include: tillage, leveling and dumping the rest of the plant. Chrysanthemum is a plant that requires the planting medium with the requirements of a particular condition is maintained during the production process [2].

Sterilization of land made to control the disease from the group of fungi and bacteria, but in this stage farmers in Pancasari not sterilize the land by reason of the condition of the land is still in good condition for the growth of newly planted plants as chrysanthemum, in addition to it as early as possible to reduce the impact of soil contamination to materials chemistry as well as necessary skills for farmers in the implementation stage of the production process. In addition to soil sterilization, production systems are not made by farmers Pancasari is the measurement of $\mathrm{EC}, \mathrm{pH}$, soil moisture, giving a growth regulator. This is due in addition to those tools are not affordable by the farmers, the work instructions of the device has not been understood by growers as the method of measurement and recording data.

The stages of the production process such as: making beds (direction, shape, width and spacing between beds), the selection of quality seeds (varieties, seed origin, resistance on plant pests and seed production), planting (method, spacing, and watering before planting), watering (method, time, frequency and adequacy of watering), fertilization (type, dose, method and time), pest control (type, dose, manner, and time), weeding (method, frequency and equipment), and environmental sanitation (methods, equipment and utilization of waste). Stages of the process over $92 \%$ of $95 \%$ following the suggestion categorized qualify, this is due to the selection of varieties of chrysanthemum growers in Pancasari still using imported seed, beyond the recommended procedure for the use of seed introduction and breeding in the country.

In the cultivation of chrysanthemums are a special production process that require attention compared to the other cut flower crops, such as: disposal of the apical growing point (pinching), pemontesan flower buds (disbunding), perompesan old leaves (senecent), chrysanthemum stem cantilever arrangement, operation of light artificial. Stages of the production process has been carried out by farmers in Pancasari chrysanthemum as required. Disposal of the apical growing point (pinching) serves to stimulate the growth of axillary shoots branching done on planting crops for the production of chrysanthemum flower spray type [2], while the flower buds pemontesan (disbunding) performed at the first flower that appears with 
the aim of provide uniform growth and development that arise from axillary buds. Chrysanthemum stems aims to help the plants grow upright plant with provision of enforcement nets, nets gradually increased along with the growth of plants. Disposal of old leaves is done to set good air circulation along with the growth of more mature plants.

TABLE IV

DATA From The Survey Component Of Production Process

\begin{tabular}{|c|c|c|c|}
\hline \multirow[b]{2}{*}{ No } & \multirow[b]{2}{*}{ Production Process } & \multicolumn{2}{|c|}{ Component } \\
\hline & & Weight & $\begin{array}{c}\text { Weight } \\
\text { Respondents }\end{array}$ \\
\hline \multirow[t]{4}{*}{1} & Tillage & 25 & 25 \\
\hline & The depth of tillage & 10 & 10 \\
\hline & Alignment of land & 5 & 5 \\
\hline & Disposal of crop residues & 10 & 10 \\
\hline \multirow[t]{5}{*}{2} & Sterilization land & 25 & 0 \\
\hline & How sterilization & 10 & 0 \\
\hline & Materials used & 5 & 0 \\
\hline & Time sterilization & 5 & 0 \\
\hline & Effectiveness sterilization & 5 & 0 \\
\hline \multirow[t]{4}{*}{3} & Making Beds & 25 & 25 \\
\hline & Direction and the form of beds & 5 & 5 \\
\hline & Width of beds & 10 & 10 \\
\hline & The distance between beds & 10 & 10 \\
\hline 4 & $\begin{array}{l}\text { Cantilever arrangement } \\
\text { chrysanthemum stems }\end{array}$ & 20 & 20 \\
\hline 5 & Operation lamp & 45 & 45 \\
\hline \multirow[t]{4}{*}{6} & $\begin{array}{l}\text { Measurement of EC, } \mathrm{pH} \text {, and soil } \\
\text { moisture }\end{array}$ & 15 & 0 \\
\hline & Methods of measurement & 5 & 0 \\
\hline & Recording of data & 5 & 0 \\
\hline & Health and the tool & 5 & 0 \\
\hline \multirow[t]{4}{*}{7.} & Liming/calcification & 20 & 5 \\
\hline & Dose / amount requirements & 10 & 0 \\
\hline & Calcification & 5 & 5 \\
\hline & Long incubation & 5 & 0 \\
\hline \multirow[t]{5}{*}{8} & Selection of Seed Quality & 80 & 63 \\
\hline & Seed varieties & 20 & 20 \\
\hline & Origin of seed & 20 & 3 \\
\hline & Resistance on the pest & 20 & 20 \\
\hline & The amount of net production & 20 & 20 \\
\hline \multirow[t]{4}{*}{9} & Planting & 25 & 25 \\
\hline & Watering before planting & 10 & 10 \\
\hline & Ways planting & 5 & 5 \\
\hline & Spacing & 10 & 10 \\
\hline \multirow[t]{5}{*}{10} & Watering the plants & 25 & 23 \\
\hline & Method of watering & 5 & 3 \\
\hline & Adequacy watering & 10 & 10 \\
\hline & Time watering & 5 & 5 \\
\hline & Frequency of watering & 5 & 5 \\
\hline \multirow[t]{10}{*}{11} & Fertilization & 40 & 31 \\
\hline & Type of fertilizer & 5 & 2 \\
\hline & Fertilization basic inorganic & 5 & 3 \\
\hline & Dose & 5 & 3 \\
\hline & Ways & 5 & 3 \\
\hline & Time & 5 & 5 \\
\hline & Dose manure & 5 & 5 \\
\hline & Ways manure application & 5 & 5 \\
\hline & Timing of manure & 5 & 5 \\
\hline & Total & 500 & 390 \\
\hline
\end{tabular}

Operation of artificial light because chrysanthemum is a short day plant (short day plants) which will naturally vegetative growth on a long day (long day plant) in the summer, and will experience growth in the short-generative in the fall with the later flowering buds forming [5]. Chrysanthemum called facultative short day plant (facultative short-day plant) this would imply that characteristics induced entry into generative phase and flowering when day length (number of hours the light) is shorter than Daylenght Critical (CDL), if the length of the plant received chrysanthemum in the juvenile period is longer than his CDL will retain the chrysanthemum plant vegetative phase [1]. In the chrysanthemum plant, the limit is 13 hours of light. This means that if a long exposure is less than 13 hours will be flowering plants [5]. On the equator, the length of day and night almost equal length, which is about 12 hours. Naturally means chrysanthemum plants will be flowering at all times, even if the plant is still shaped seeds. To obtain a standard stem length of cut flower chrysanthemum in accordance with the market demand that is at least $60 \mathrm{~cm}$ and a maximum of $80 \mathrm{~cm}$. So chrysanthemum plants require additional lighting for 4 hours per day with the optimum light intensity between 70-100 lux. In general, additional light is given continuously or cycle for 3 to 6 weeks after planting; depending on cultivation techniques and kultivar [4].

\section{Harvest and Post Harvest Handling}

The timing of harvest, harvesting, sorting and grading was performed according to the terms in the system recommended procedure chrysanthemum production by farmers in the village Pancasari (Table 5). Harvest is a critical point in the business of cut flowers, including chrysanthemum, harvesting should be done at appropriate harvest index provisions, as appropriate harvest flower quality can not be improved unless the maximum is only maintained [2]. Sorting and grading aims to separate the flowers are damaged or defective due to pest attack and physical damage to healthy flowers. The best quality of chrysanthemum flowers as cut flowers produced during the production process must be maintained during harvest and post harvest.

Soaking flower stalk, flower storage, packaging and packing requirements not meet recommended procedure, entirely done by the farmers in the village Pancasari chrysanthemum, farmers in the process of soaking the flower stalk does not use preservatives either preservative composition, dosage and concentration as required, it this does not take full account of the distribution channels can be reached in a short time so that the condition of interest to the consumer is still in a good quality and to reduce manufacturing costs.

\section{E. Other components}

Other components are used as indicators concerning: the obstacles in the cultivation of chrysanthemum, the product absorbed by the market, consumers preferred varieties, production absorbed by the market, and the resulting production. Component above $75 \%$ can only qualify the recommended procedure, because of the constraints cultivation attack plant pests (leaf rust) and not continuous supply of seeds from seed producers so that continuity can not be run in accordance planting calendar will affect consumer confidence. The resulting production to market needs is still low when compared with the absorption of the market, since the average production capabilities of farmers between 10,000-50,000 chrysanthemum stems per season. 
TABLE V

DATA FROM THE SURVEY COMPONENT OF HARVEST AND POST-HARVEST HANDLING

\begin{tabular}{|c|c|c|c|}
\hline \multirow[b]{2}{*}{ No } & \multirow{2}{*}{$\begin{array}{c}\text { Harvest and Post-Harvest } \\
\text { Handling }\end{array}$} & \multicolumn{2}{|c|}{ Component } \\
\hline & & Weight & $\begin{array}{c}\text { Weight } \\
\text { Respondents }\end{array}$ \\
\hline \multirow[t]{3}{*}{1} & The timing of harvest & 40 & 40 \\
\hline & Criterion for harvest & 20 & 20 \\
\hline & Mechanical harvester & 20 & 20 \\
\hline \multirow[t]{5}{*}{2} & Harvesting & 30 & 30 \\
\hline & Tool condition & 5 & 5 \\
\hline & Cutting the flower stalk & 5 & 5 \\
\hline & Storage & 10 & 10 \\
\hline & Immersion & 10 & 10 \\
\hline \multirow[t]{4}{*}{3} & Sorting and Grading & 40 & 40 \\
\hline & The process of sorting and grading & 15 & 15 \\
\hline & Sorting and grading & 15 & 15 \\
\hline & Packaging and labeling & 10 & 10 \\
\hline \multirow[t]{6}{*}{4} & Soaking flower stalk & 30 & 15 \\
\hline & Preservatives & 5 & 0 \\
\hline & The composition of the active & & 0 \\
\hline & Concentration and dose & 5 & 0 \\
\hline & Place used to soak & 5 & 5 \\
\hline & Length of flower stalks are soaked & 10 & 10 \\
\hline \multirow{5}{*}{5} & Storage Flowers & 30 & 15 \\
\hline & Storage & 10 & 5 \\
\hline & Temperature / humidity room & 5 & 0 \\
\hline & Grade grouping in storage & 10 & 10 \\
\hline & Immersion flower stalk & 5 & 0 \\
\hline \multirow[t]{6}{*}{6} & Packaging and Packing & 30 & 20 \\
\hline & The packaging & 10 & 5 \\
\hline & Forms and packaging materials & 5 & 5 \\
\hline & Identification of the company & 5 & 0 \\
\hline & The size and shape of the packing & 10 & 10 \\
\hline & Total & 200 & 160 \\
\hline
\end{tabular}

TABLE VI

DATA From THE SURVEY COMPONENT OF OTHER COMPONENTS

\begin{tabular}{|c|c|c|c|}
\hline \multirow[b]{2}{*}{ No } & \multirow[b]{2}{*}{ Other Components } & \multicolumn{2}{|c|}{ Component } \\
\hline & & Weight & $\begin{array}{c}\text { Weight } \\
\text { Respondents }\end{array}$ \\
\hline \multirow[t]{7}{*}{1} & $\begin{array}{l}\text { Constraints cultivation of } \\
\text { chrysanthemums }\end{array}$ & 25 & 5 \\
\hline & Product absorbed by the market & 25 & 25 \\
\hline & Varieties preferred by consumers & 10 & 10 \\
\hline & $\begin{array}{l}\text { Prospects of cultivation of } \\
\text { chrysanthemum }\end{array}$ & 20 & 20 \\
\hline & Production absorbed by the market & 10 & 10 \\
\hline & Production produced & 10 & 5 \\
\hline & Total & 100 & 75 \\
\hline
\end{tabular}

\section{CONCLUSIONS}

Potential agroclimate Pancasari villages, districts Sukasada, Buleleng regency has the potential locations for the cultivation of chrysanthemum as a mainstay commodity. Infrastructure chrysanthemum cultivation by farmers in the village Pancasari have met the criteria in the procedure of the production system. Other infrastructure tailored to the knowledge, capabilities and functions. The production process is carried out by farmers in the village Pancasari has been conducted in accordance with the recommended procedure, but there are several processes performed by the local environmental conditions, ability and habits of farmers.

Implementation of harvest and post-harvest handling by farmers in the village of chrysanthemum Pancasari been applied according to the procedure, while the immersion activities flower, flower storage, packaging and packing not meet the recommended requirements. Constraints faced by farmers in the village Pancasari chrysanthemum is the availability of seeds that are not continuous, attack plant pests, and production capacity is still low. Further studies need to be done on the survey results, and the motivating factors that can be used as a reference in order to generate recommendations technology implementation cuttings. Chrysanthemum cultivation technology is specific agroecological, varieties and farmers markets chrysanthemum flower producers are expected to adapt to existing conditions, and build the field of empirical experience with the application of existing technology.

\section{ACKNOWLEDGMENT}

Much obliged for $\mathrm{DP}_{2} \mathrm{M}$ DIKTI which have funded Decentralization Research Competitive Grant in 2014. Thanks also goes to all those who have helped this research.

\section{REFERENCES}

[1] Balai Penelitian Tanaman Hias, 2006. Teknologi Produksi Krisan. Pusat Penelitian dan Pengembangan Hortikultura Badan Penelitian dan Pengembangan Pertanian.

[2] Budiarto, K., Yoyo Sulyo, Ruud Maaswinkel dan Sri Wuryaningsing, 2006. Budidaya Krisan Bunga Potong, Prosedur Sistem Produksi. Pusat Penelitian dan Pengembangan Hortikultura, Applied Plant Research (PPO), the Netherlands, Plant Research International (PRI)

[3] Direktorat Budidaya Tanaman Hias. 2007. Standar Operasional Produser Budidaya Krisan Potong. Direktorat Jenderal Hortikultura. Departemen Pertanian, Jakarta.

[4] Fides,1990. Fides Mum Manual (Delier: Fides Holland BV)

[5] Kofranek, A.M. 1980. Cut Crysanthemum, In RA Larson (Ed.). Introduction to Floriculture. Academic Press, Inc. New York.

[6] Monografi Desa Pancasari Kecamatan Sukasada, Kabupaten Buleleng 2012

[7] Rudianta, I Nyoman dan I GD. Pasek Mangku, 2013. Alternatif Strategi Pengembangan Agribisnis Bunga Krisan. Gema Agro Fakultas Pertanian Universitas Warmadewa Denpasar. Jurnal Pertanian Vol. XIV. No. 33. September 2013.

[8] Rukmana, HR. 1997. Krisan. Penerbit Kanisius. Yogyakarta 